\title{
Peertechz
}

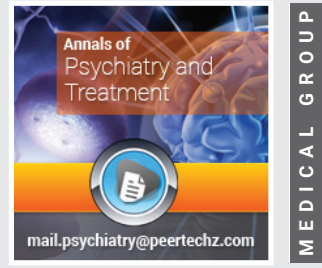

\section{An experimental study targeting N-methyl- D-aspartate receptor in depression; beyond ketamine}

Received: 02 December, 2020

Accepted: 12 December, 2020

Published: 15 December, 2020

*Corresponding author: Dr. Bushra Ahmed Karim, Assistant Professor, Department of Public Health Dentistry, Jamia Millia Islamia, New Delhi 110025 India, Tel: 091-8470923822;

E-mail: bushrakarim786@gmail.com

Keywords: Depression; NMDA; Ketamine; Glycine https://www. peertechz.com

\section{Check for updates}

\section{Salim Sheikh ${ }^{1,2}$, Pankaj Sonone ${ }^{2}$, Chakar Dhar Tripathi ${ }^{1,2}$, Veena Verma ${ }^{2}$ and Bushra Ahmed Karim ${ }^{3 *}$}

1Department of Pharmacology, ESIC Medical College \& Hospital, 121001, Faridabad

${ }^{2}$ Department of Pharmacology, VMMC \& Safdarjung Hospital, New Delhi 110029, India

${ }^{3}$ Department of Public Health Dentistry, Jamia Millia Islamia, New Delhi 110025, India

\section{Abstract}

Objective: Despite the availability of vast group of drugs, treatment of depression still remains unsatisfactory. Serious adverse effects of anti-depressants lead to early withdrawal from treatment. One more important concern is the therapeutic lag of nearly 3-4 weeks. Therefore, newer targets for drugs with good safety profile, rapid onset of action and with substantial benefits in comparison to conventional therapy need to be explored.

Method: 10 groups of 6 mice each were evaluated for immobility time in TST and FST. Treatment used was normal saline (control), citalopram, ketamine, glycine and combination of ketamine with glycine.

Results: Significant decrease in immobility time was observed in ketamine treated mice in both models. Citalopram decreased the immobility time in both models but it was not significant in FST. Glycine treated mice showed a significant increase in immobility time in both. Ketamine and glycine combination also increased the immobility time, though, it was not significant.

Conclusion: Ketamine have an antidepressant activity of its own which could be attributed to involvement of NMDA receptors and its interaction with the monoaminergic system. On the other hand, glycine, a co-agonist of NMDA receptor elicited a depressant effect. Moreover, their combination favored towards depressant effect.

\section{Introduction}

Depression is the most prevalent mood disorder in the world $[1,2]$. More than $30 \%$ of them have major depressive disorder (MDD) [3] experiencing high relapse rate, residual symptoms, functional impairment, and an increase suicidal tendency [4]. Therefore, it's prudent to not only gain more knowledge about the etiologies of depression, but also, explore novel agents for its treatment.

Presently, the armamentarium of drugs against depression include tricyclic antidepressants, monoamine oxidase inhibitors, norepinephrine and serotonin reuptake inhibitors, serotonin-norepinephrine reuptake inhibitors (SNRIs), selective serotonin reuptake inhibitors (SSRIs) and atypical anti-depressants [5]. The neurotransmitters targeted are primarily serotonin (5-HT), norepinephrine and dopamine. However, SNRI and SSRI drugs are preferred owing to less adverse effects and low toxicity profile $[6,7]$.

Despite the availability of vast group of drugs, treatment of depression still remains unsatisfactory, largely due to differential efficacy of antidepressants at adequate doses resulting in treatment refractive depression [8]. In addition, serious adverse effects of anti-depressants also leads to early withdrawal from treatment [9]. One more important concern is the therapeutic lag of nearly 3-4 weeks, before some appreciable clinical effect. This is the period when there is high 
risk of suicide [10]. Therefore, newer targets for drugs with good safety profile, rapid onset of action and with substantial benefits in treating patients who are either refractory or resistant to conventional therapy, need to be explored.

In this pursuit, focus has now shifted to drugs acting and modulating the N-Methyl-D-Aspartate receptor family. Ketamine is a non-competitive NMDA antagonist which produces rapid, sustained and enhanced antidepressant with decreased therapeutic lag, but with profound adverse effects like psychotomimetic symptoms, abuse potential, neurotoxicity and cognitive impairment [11-13]. However, agents acting on the glycine modulatory site of the NMDA receptor are devoid of such side effects and still produce rapid and sustained antidepressant effects $[14,15]$. Therefore, the present study was carried out to further elucidate the role of ketamine and glycine in animal models of depression.

\section{Methods}

The study has been conducted in department of Pharmacology of a tertiary teaching care hospital in New Delhi. Swiss Albino male mice weighing between 22-25 g were utilized for this study. The animals were kept under standard laboratory conditions. The animals were housed in standard laboratory conditions (12-h light/dark cycle, $21 \pm 1^{\circ} \mathrm{C}$, and relative humidity of $55 \pm 5 \%$ ) with free access to food and water prior to the experiments. After 7 days of acclimatization to laboratory conditions, the animals were randomly assigned to experimental groups, each consisting of 6 mice. Each animal was used only once in the experimental procedures. All experiments were carried out between 9 a.m. and 3 p.m. The control groups were studied concurrently with the experimental groups. All experimental procedures were carried out after being approved (VMMC/IAEC/2013/14) by the Institutional Animals Ethics Committee. The normal saline and ketamine were procured from the drug store department of the hospital, whereas citalopram and glycine was provided by Sigma Aldrich, India. The treatment was given as per treatment design (Table 1).

Animals were randomly allocated into the different groups (Table 2), each group comprising of six mice. The experiments were performed between 9:00 am and 3:00 pm. The antidepressant effect was assessed by FST \& TST. The drugs were injected intra-peritoneal (ip) $60 \mathrm{~min}$ before conducting the test session. Control group received appropriate vehicle (normal saline). The dose of citalopram for present study was based on dose used in previous study [16] whereas doses of glycine and ketamine were selected on the basis of pilot studies. While giving drugs in combination, doses of drugs were reduced to half.

The FST is a rodent behavioral test used for evaluation of antidepressant drugs and antidepressant efficacy of new compounds [17-19]. Mice are placed in an inescapable transparent tank that is filled with water and their escape related mobility behavior is measured. The cylindrical tanks (30 cm height $\mathrm{x} 20 \mathrm{~cm}$ diameters) required for the forced swim test (FST) of transparent Plexiglas was used. The water level was $15 \mathrm{~cm}$ from the bottom and marked on the tank to ensure
Table 1: Treatment design of the study.

\begin{tabular}{|c|c|c|}
\hline Drugs & Forced Swim Test & Tail Suspension Test \\
\hline $\begin{array}{l}\text { Normal } \\
\text { Saline }\end{array}$ & Single dose of 0.2 to $0.3 \mathrm{ml}$ i.p. & Single dose of 0.2 to $0.3 \mathrm{ml}$ i.p. \\
\hline Citalopram & $\begin{array}{c}\text { Single Dose Of } 10 \mathrm{mg} / \mathrm{Kg} \text { Body } \\
\text { Weight I.P. }\end{array}$ & $\begin{array}{c}\text { Single Dose Of } 10 \mathrm{mg} / \mathrm{Kg} \text { Body } \\
\text { Weight I.P. }\end{array}$ \\
\hline Ketamine & $\begin{array}{c}\text { Single Dose Of } 35 \mathrm{mg} / \mathrm{Kg} \text { Body } \\
\text { Weight I.P. }\end{array}$ & $\begin{array}{c}\text { Single Dose Of } 35 \mathrm{mg} / \mathrm{Kg} \text { Body } \\
\text { Weight I.P. }\end{array}$ \\
\hline Glycine & $\begin{array}{c}\text { Single dose of } 100 \mathrm{mg} / \mathrm{kg} \text { body } \\
\text { weight i.p. }\end{array}$ & $\begin{array}{l}\text { Single dose of } 100 \mathrm{mg} / \mathrm{kg} \text { body } \\
\text { weight i.p. }\end{array}$ \\
\hline $\begin{array}{l}\text { Ketamine + } \\
\text { glycine }\end{array}$ & $\begin{array}{l}\text { Single dose of } 20 \mathrm{mg} / \mathrm{kg}+50 \mathrm{mg} / \\
\mathrm{kg} \text { body weight i.p. }\end{array}$ & $\begin{array}{l}\text { Single dose of } 20 \mathrm{mg} / \mathrm{kg}+50 \mathrm{mg} / \mathrm{kg} \\
\text { body weight i.p. }\end{array}$ \\
\hline
\end{tabular}

Table 2: Study design of animal model of depression.

\begin{tabular}{|l|l|}
\hline \multicolumn{1}{|c|}{ Animal model } & \multicolumn{1}{c}{ Groups $(\mathbf{n = 6})$} \\
\hline & a. Control \\
\hline \multirow{3}{*}{ Forced swim test } & b. Ketamine \\
& c. Citalopram \\
& d. Glycine \\
& e. Ketamine+Glycine \\
\hline \multirow{3}{*}{ Tail suspension test } & a. Control \\
& b. Ketamine \\
& c. Citalopram \\
& d. Glycine \\
& e. Ketamine+Glycine \\
\hline
\end{tabular}

that the volume of water is consistent over experiment. The dimensions of the tanks were selected in a way that the mice would not be able to touch the bottom of the tank, either with their feet or their tails, during the swimming test. The height of the tank was high enough to prevent the mice escaping from the tank. The apparatus was cleaned thoroughly, and water was changed from mice to mice. Two swimming sessions were conducted and videotaped: $15 \mathrm{~min}$ on the 1st day as a training session followed by $6 \mathrm{~min}$ (test session) on the 2nd day. After each test, the mice were dried and kept warm under a heating bulb for 30 min before being returned to their home cages. Mice were injected with single dose test drugs just before conducting test session. Behavior was videotaped and immobility time was recorded (Day 1 ).

Tail Suspension Test (TST) was developed as a rodent screening test for potential (human) antidepressant drugs $[20,21]$. It is based on the assumption that an animal will actively try to escape an aversive stimulus. If escape is impossible, the animal will eventually stop trying ("give up"). In this test mice were both acoustically and visually isolated and suspended 50 $\mathrm{cm}$ above the floor by adhesive tape placed approximately $1 \mathrm{~cm}$ from the tip of the tail. Immobility time was recorded during a 6 min period. Mice were considered immobile only when they were completely motionless. The parameter recorded was the time spent immobile.

The mean+SEM of the immobility time was calculated and the data were analyzed using one way analysis of variance (ANOVA) followed by Tukey"s multiple range test, wherever applicable. $P$ values less than 0.05 were considered significant.

\section{Results}

Both ketamine and citalopram when given alone demonstrated significant decrease in immobility time and 
increase in duration of struggle as compared to control group, suggesting an antidepressant like effect. On comparisons of the control group immobility time with that of ketamine and citalopram, it was observed that both drugs reduced the immobility time and increase the time spent in struggle, although decrease in immobility time was more pronounced with ketamine than with citalopram. On the contrary, Glycine administration caused significant increase in the immobility time (Figure 1).

When glycine alone and glycine in combination with ketamine were administered, both the group demonstrated increase in immobility time and decrease in duration of struggle as compared to control group, but the increase were significant in the glycine group only (Figure 2).

When ketamine was administered it significantly reduce the immobility time and increase the duration of struggle as compared with control group, suggesting an antidepressantlike effect, On the other hand, citalopram decreased the immobility time but the effect was not significant. However, there was a significant increase in the immobility time in the group treated with glycine (Figure 3).

Glycine was given alone caused significant increase in the immobility, but when it was given along with ketamine, they demonstrated a non significant increment in immobility time and decrease the duration of struggle as compared to control group (Figure 4).

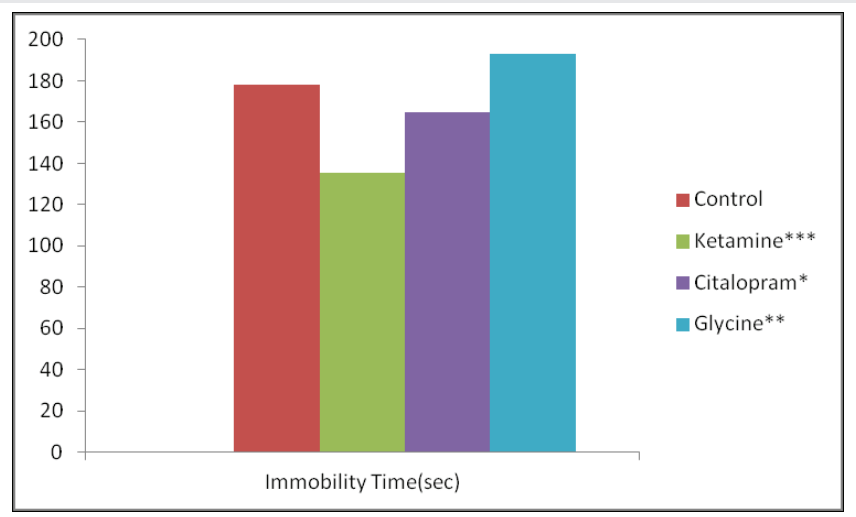

Figure 1: Effect of Normal Saline, ketamine, Citalopram and Glycine on immobility time in TST. $(P<0.05 *, P<0.01 * *, P<0.001 * * *)$.

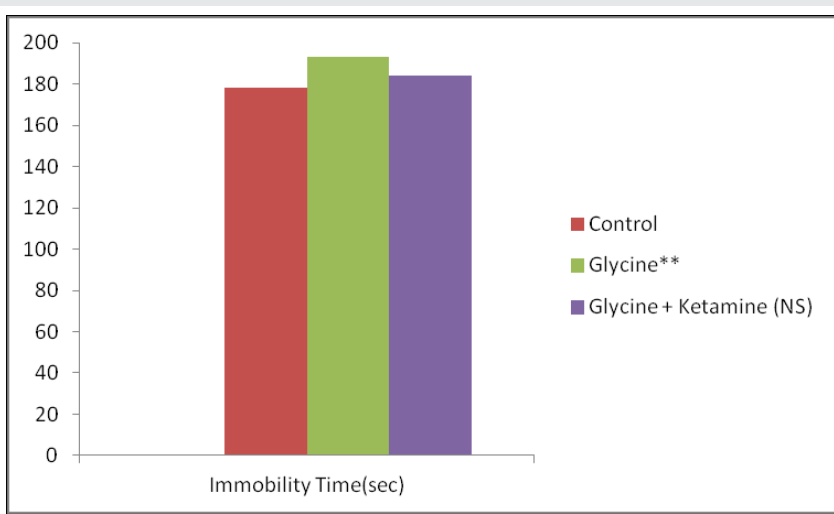

Figure 2: Effect of Normal Saline, Glycine and Ketamine+Glycine $(K+G)$ on immobility time in TST. $\left({ }^{*} \mathrm{P}<0.05,{ }^{*} \mathrm{P}<0.01, \mathrm{NS}-\right.$ Non Significant).

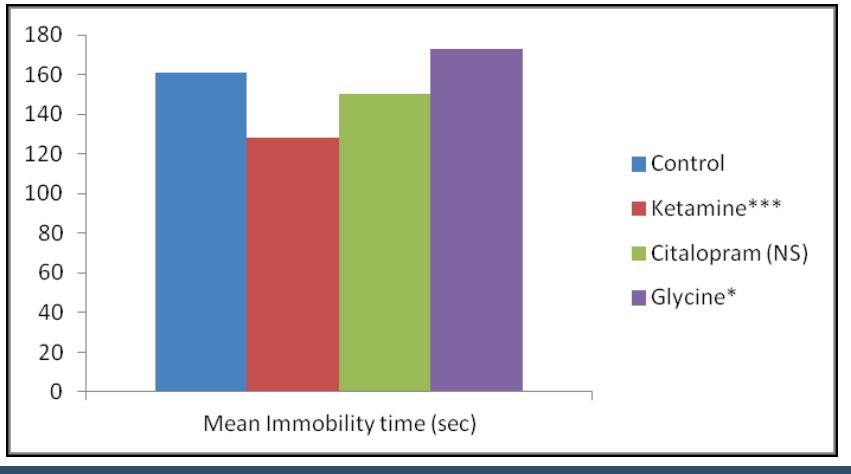

Figure 3: Effect of Normal Saline, Citalopram, Ketamine and Glycine on immobility time in FST $\left({ }^{*} \mathrm{P}<0.05,{ }^{*} \mathrm{P}<0.01,{ }^{*} \mathrm{P}<0.001\right)$

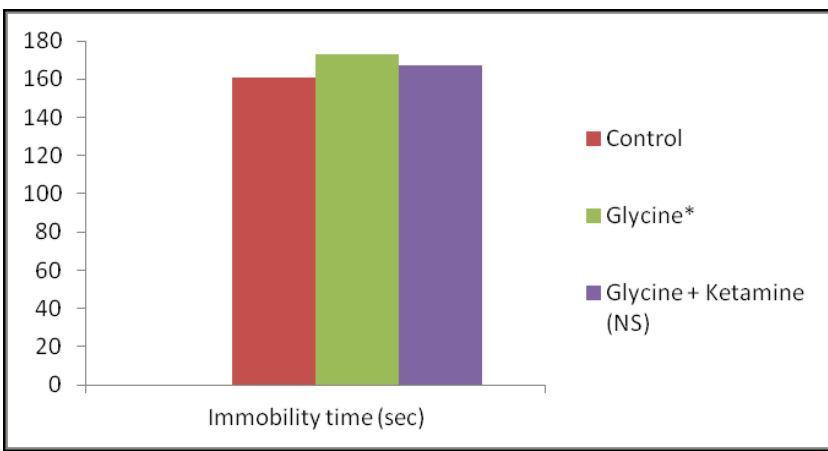

Figure 4: Effect of Normal Saline, Glycine and Ketamine+Glycine $(K+G)$ on immobility time in FST ( ${ }^{\mathrm{P}}<0.05$, NS- Non Significant).

\section{Discussion}

Major challenges in modern day anti-depressant therapy are delay in the therapeutic response and inadequate improvement along with poor patient compliance due to adverse effects [8]. In addition to monoamine hypothesis of depression, it is now well established that both pathophysiology of depression and effect of antidepressant treatments involve neuroplasticity (e.g. hippocampal neurogenesis, expression of the brain-derived neurotrophic factors (BDNF) and hypothalamic pituitaryadrenal (HPA) axis modulation [22-25]. Therefore, newer drugs targeting them with rapid onset and longer sustainable effect are the need of the hour. In our study, we investigated the effect of citalopram (SSRI), ketamine (NMDA receptor antagonist) and glycine (NMDA receptor co agonist) in animal models of depression (TST \& FST). These tests have good predictive validity and allow rapid and economical detection of drugs with potential antidepressant like activity. Testing of new substances in these tests allow a simple assessment of their potential for antidepressant activity [26].

In our study citalopram caused significant reduction in the immobility time and increased the struggle period in TST, further strengthening its anti-depressant effect [27]. This effect of SSRIs is due to inhibition of SERT, leading to increase availability of serotonin at the postsynaptic receptor site due to reuptake inhibition. However, citalopram failed to show significant anti-depressant effect in FST. It is due to the use of single dose only because of constraint of animal. This is similar to other studies where single dose of citalopram did not decreased the immobility time significantly $[28,29]$. 
Interestingly, chronic administration of citalopram and fluoxetine caused significant reduction in the immobility time [28-30], probably explaining the therapeutic lag seen in SSRIs.

On the other hand, ketamine showed significant decrease in immobility time both in FST \& TST models. This is similar to the study showing dose dependent decrease in immobility time by MK-801, ketamine \& imipramine, but not by fluoxamine [31]. This effect of ketamine in present study could probably be explained by an NMDA receptor antagonism. The other reasons for the decrease are increase in Brain Derived Neurotropic Factor level and activation of mammalian target of rapamycin (mTOR), leading to an increase in synaptic signaling protein in the pre frontal cortex [32-34].

In our study, we also tried to investigate the effect of glycine on immobility time in FST \& TST models. We selected the dose of glycine on the basis of pilot study. On administration of glycine at a dose of $500 \mathrm{mg} / \mathrm{kg}$ mortality was observed, whereas when there was marked reduction in locomotor activity at the dose of $250 \mathrm{mg} / \mathrm{kg}$ and $200 \mathrm{mg} / \mathrm{kg}$. Therefore, we selected $100 \mathrm{mg} / \mathrm{kg}$ of dose for our study. When administered alone, glycine showed significant increase in immobility time in both FST \& TST. But when glycine was combined with ketamine, there was a increase in the immobility time but the effect was not significant. Action of glycine on strychnine sensitive site $\left(\right.$ glycine $_{\mathrm{A}}$ ) in brainstem \& hippocampus or its effect on strychnine insensitive site at NMDA receptor $\left(\right.$ glycine $_{B}$ ) and its activation could be the probable explanation [35]. We could not conclude whether this effect was due to glycine binding on glycine ${ }_{A}$ or glycine ${ }_{B}$ site, for which further studies using specific agonist and antagonist at glycine ${ }_{\mathrm{B}}$ site are needed. Both partial agonist \& antagonist at glycine ${ }_{\mathrm{B}}$ site of NMDA receptor has shown antidepressant activity $[14,36]$, this complex mechanism behind the glycine ${ }_{B}$ site of NMDA receptor needs further evaluation.

\section{Conclusion}

Ketamine have an antidepressant activity of its own, as shown in both TST \& FST models which could be attributed to involvement of NMDA receptors and its interaction with the monoaminergic system. On the other hand, Glycine, a coagonist of NMDA receptor elicited a depressant effect. Moreover, their combination favored towards depressant effect.

\section{Author contributions}

All authors have accepted responsibility for the entire content of this manuscript and approved its submission.

\section{References}

1. Moussavi S, Chatterji S, Verdes E, Tandon A, Patel V, et al. (2007) Depression, chronic diseases, and decrements in health: results from the World Health Surveys. Lancet 370: 851-858. Link: https://bit.ly/381AZ0n

2. Kessler RC, Berglund P, Demler O, Jin R, koretz D, et al. (2003) The epidemiology of major depressive disorder: results from the National Comorbidity Survey Replication(NCS-R). JAMA 289: 3095-3105. Link: https://bit.ly/347SfQq

3. Thase ME (2000) Treatment of severe depression. J Clin Psychiatry 61: 17-25.

4. Pattanayak RD, Sagar R (2014) Depressive Disorders in Indian Context : A
Review and Clinical Update for Physicians. J Assoc Physicians India 62: 827 832. Link: https://bit.ly/3nfq49K

5. Mendlewicz J (2001) Optimising antidepressant use in clinical practice: towards criteria for antidepressant selection. Br J Psychiatry 179: S1-3. Link: https://bit.ly/3oQeltm

6. Ellis $P$ (2004) Australian and New Zealand clinical practice guidelines for the treatment of depression. Aust N Z J Psychiatry 38: 389-407. Link: https://bit.ly/3mkKnBf

7. Roose SP (2003) Compliance: the impact of adverse events and tolerability on the physician's treatment decisions. Eur Neuropsychopharmacol 13: S85-92. Link: https://bit.ly/3qTDg6x

8. Al-Harbi KS (2012) Treatment-resistant depression: therapeutic trends, challenges, and future directions. Patient Prefer Adherence 6: 369-388. Link: https://bit.ly/3me5PYD

9. Cartwright C, Gibson K, Read J, Cowan O, Dehar T (2016) Long-term antidepressant use: patient perspectives of benefits and adverse effects. Patient Prefer Adherence 10: 1401-1407. Link: https://bit.ly/37WaoS

10. Selvaraj V, Veeravalli S, Ramaswamy S, Balon R, Yeragani VK (2010) Depression, suicidality and antidepressants: A coincidence? Indian J Psychiatry 52: 17-20. Link: https://bit.ly/383uA4H

11. Szewczyk B, Pałucha-Poniewiera A, Poleszak E, Pilc A, Nowak G (2012) Investigational NMDA receptor modulators for depression. Expert Opin Investig Drugs 21: 91-102. Link: https://bit.ly/3a7ikTv

12. Zarate CA, Singh JB, Carlson PJ, Brutsche NE, Ameli R (2006) A randomized trial of an $\mathrm{N}$ - methyl-D-aspartate antagonist in treatment-resistant major depression. Arch Gen Psychiatry 63: 856-864. Link: https://bit.ly/3nkjSgE

13. Skolnick P, Popik P, Trullas R (2009) Glutamate-based antidepressants: 20 years on. Trends Pharmacol Sci 30: 563-569. Link: https://bit.ly/3abzsaK

14. Burgdorf J, Zhang $\mathrm{XL}$, Nicholson $\mathrm{KL}$, Balster $\mathrm{RL}$, Leander JD, et al. (2013) GLYX-13, a NMDA receptor glycine-site functional partial agonist induces antidepressant-like effects without ketamine-like side effects. Neuropsychopharmacology 38: 729-742. Link: https://bit.ly/3oPbUwx

15. Burgdorf J, Zhang XL, Weiss C, Gross A, Boikess SR, et al. (2015) The long lasting antidepressant effects of rapastinel (GLYX-13) are associated with a metaplasticity process in the medial prefrontal cortex and hippocampus. Neuroscience 308: 202-211. Link: https://bit.ly/3qSZjKp

16. Bezchlibnyk-Butler K, Aleksic I, Kennedy SH (2000) Citalopram-a review of pharmacological and clinical effects. J Psychiatry Neurosci 25: 241-254. Link: https://bit.ly/34710vm

17. Porsolt RD, Le Pichon $M$, Jalfre $M$ (1977) Depression: a new anima model sensitive to antidepressant treatments. Nature 266: 730-732. Link: https://bit.ly/2KqXWSr

18. Borsini F, Meli A (1988) Is the forced swimming test a suitable model fo revealing antidepressant activity? Psychopharmacology 94: 147-160. Link: https://bit.ly/37doGis

19. Lucki I (1997) The forced swimming test as a model for core and componen behavioral effects of antidepressant drugs. Behav Pharmacol 8: 523-553. Link: https://bit.ly/3qNnbPE

20. Steru L, Chermat R, Thierry B, Simon P (1985) The tail suspension test: a new method for screening antidepressants in mice. Psychopharmacology 85: 367 370. Link: https://bit.ly/3a4D0M1

21. Cryan JF, Mombereau C, Vassout A (2005) The tail suspension test as a model for assessing antidepressant activity: review of pharmacological and genetic studies in mice. Neurosci Biobehav Rev 29: 571-625. Link: https://bit.ly/3mgUS91

Citation: Sheikh S, Sonone P, Tripathi CD, Verma V, Karim BA (2020) An experimental study targeting N-methyl-D-aspartate receptor in depression; beyond ketamine. Ann Psychiatry Treatm 4(1): 057-061. DOI: https://dx.doi.org/10.17352/apt.000021 
22. Hardingham GE, Fukunaga $Y$, Bading $H$ (2002) Extrasynaptic NMDARs oppose synaptic NMDARs by triggering CREB shut-off and cell death pathways. Nat Neurosci 5: 405-414. Link: https://bit.ly/3oJyRkw

23. Vanhoutte P, Bading $H$ (2003) Opposing roles of synaptic and extrasynaptic NMDA receptors in neuronal calcium signalling and BDNF gene regulation Curr Opin Neurobiol 13: 366-371. Link: https://bit.ly/3nfG4sw

24. Kunugi H, Hori H, Adachi N, Numakawa T (2010) Interface between hypothalamic-pituitary adrenal axis and brain-derived neurotrophic factor in depression. Pychiat Clin Neurosci 64: 447-459. Link: https://bit.ly/381YgPH

25. Faure C, Mnie-Filali O, Haddjeri N (2006) Long-term adaptive changes induced by serotonergic antidepressant drugs. Expert Rev Neurother 6: 235-245. Link: https://bit.ly/3mbOtvv

26. Castagne V, Moser P, Roux S, Porsolt RD (2011) Rodent models of depression: forced swim and tail suspension behavioral despair tests in rats and mice. Curr Protoc Neurosci 8: 10. Link: https://bit.ly/2WdrPs8

27. Sanchez C, Meier E (1997) Behavioral profiles of SSRIs in animal models of depression, anxiety and aggression. Are they all alike? Psychopharmacology 129: $197-205$

28. Mombereau C, Gur TL, Onksen J, Blendy JA (2010) Differential effect of acute and repeated citalopram in mouse model of anxiety and depression. Int $J$ Neuropsychopharmacol 13: 321-334. Link: https://bit.ly/2WeeUX8

29. Dulawa SC, Holick KA, Gundersen B, Hen R (2004) Effects of Chronic Fluoxetine in Animal Models of Anxiety and Depression. Neuropsychopharmacology 29 : 1321-1330. Link: https://bit.ly/34cnsC5
30. Cryan JF, Page ME, Lucki I (2005) Diffrential behavioral effect of the antidepressant reboxtine, fluoxetine and moclobemide in a modified forced swim test following chronic treatment. Psychopharmacology 182: 335-344. Link: https://bit.ly/349DzjE

31. Rogoz Z, Skuza G, Maj J, Danysz W (2002) Synergistic effect of uncompetitive NMDA receptor antagonists and antidepressant drugs in the forced swimming test in rats. Neuropharmacol 42: 1024-1030. Link: https://bit.ly/3r1rrvh

32. Reus GZ, Stringari RB, Kirsch TR, Fries GR, Kapczinski F, et al. (2010) Neurochemical and behavioural effects of acute and chronic memantine administration in rats: Further support for NMDA as a new pharmacological target for the treatment of depression? Brain Res Bull 81: 585-589. Link: https://bit.ly/3qTTrRi

33. Autry AE, Adachi M, Nosyreva E, Na ES, Los MF, et al. (2011) NMDA receptor blockade at rest triggers rapid behavioural antidepressant responses. Nature 475: 91-95. Link: https://bit.ly/3mc9YMZ

34. Mathew JS, Shah A, Lapidus K, Clark C, Jarun N, et al. (2012) Ketamine for Treatment-Resistant Unipolar Depression. CNS Drugs 26: 189-204. Link: https://bit.ly/37dENwf

35. Poleszak E, Wlaz P, Szewczyk B, Wlaz A, Kasperek R, et al. (2011) A complex interaction between glycine/NMDA receptors and serotonergic/noradrenergic antidepressants in the forced swim test in mice. J Neural Transm 118: 15351546. Link: https://bit.ly/37dEMIH

36. Zhu WL, Wang SJ, Liu MM, Shi HS, Zhang RX, et al. (2013) Glycine site $\mathrm{N}$-methyl-D- aspartate receptor antagonist 7-CTKA produces rapid antidepressant-like effects in male rats. J Psychiatry Neurosci 38: 306-316. Link: https://bit.ly/2LyBbNb

\section{Discover a bigger Impact and Visibility of your article publication with}

\section{Peertechz Publications}

\section{Highlights}

* Signatory publisher of ORCID

- Signatory Publisher of DORA (San Francisco Declaration on Research Assessment)

* Articles archived in worlds' renowned service providers such as Portico, CNKI, AGRIS, TDNet, Base (Bielefeld University Library), CrossRef, Scilit, J-Gate etc.

* Journals indexed in ICMJE, SHERPA/ROMEO, Google Scholar etc.

- OAI-PMH (Open Archives Initiative Protocol for Metadata Harvesting)

* Dedicated Editorial Board for every journal

* Accurate and rapid peer-review process

* Increased citations of published articles through promotions

* Reduced timeline for article publication

Submit your articles and experience a new surge in publication services (https://www.peertechz.com/submission).

Peertechz journals wishes everlasting success in your every endeavours.

Copyright: @ 2020 Sheikh S, et al. This is an open-access article distributed under the terms of the Creative Commons Attribution License, which permits unrestricted use distribution, and reproduction in any medium, provided the original author and source are credited.

Citation: Sheikh S, Sonone P, Tripathi CD, Verma V, Karim BA (2020) An experimental study targeting N-methyl-D-aspartate receptor in depression; beyond ketamine Ann Psychiatry Treatm 4(1): 057-061. DOI: https://dx.doi.org/10.17352/apt.000021 